\title{
Respons Pertumbuhan Bibit Kakao (Theobroma cacao L.) terhadap Pemberian Dosis Slurry pada Ultisols Hajimena
}

\section{(The Growth Response of Cocao Seedlings [Theobroma cacao L.] to Slurry Doses in Ultisols Hajimena)}

\author{
Lurfhia Haida Hakim ${ }^{1 *}$, Rijadi Subiantoro ${ }^{2)}$, Fatahillah ${ }^{2)}$ \\ 1) Program Studi Produksi dan Manajemen Industri Perkebunan, Politeknik Negeri Lampung Jl. \\ Soekarno-Hatta No.10 Rajabasa, Bandar Lampung, 35144, Telp.: (0721) 703995, Fax.: (0721) \\ 787309 dan 2) Jurusan Budidaya Tanaman Perkebunan, Politeknik Negeri Lampung Jl. \\ Soekarno-Hatta No.10 Rajabasa, Bandar Lampung, 35144, Telp.: (0721) 703995, Fax.: (0721) \\ 787309 \\ E-mail: lurfhiahaidahakimm25@yahoo.com
}

\begin{abstract}
This study aims to obtain the best slurry dosage for the growth of cocoa seedlings. This reaserch was conducted in the experimental garden, chemical analyzed laboratory, and soil laboratory of Politeknik Negeri Lampung on November 2017 until March 2018. The method used was a Completely Randomized Design (CRD) with 6 doses of slurry $(0 \mathrm{ml}, 80$ $\mathrm{ml}, 160 \mathrm{ml}, 240 \mathrm{ml}, 320 \mathrm{ml}$, and $400 \mathrm{ml}$ ). Observation variables in the form of premilinary observations abd observations during the study. Preliminary observations analyzed the levels of $N, P, K, p H$, and C-Organic on topsoil and slurry. Obsevation during the study were plant height, stem diameter, number of leaves, dry weight of shoot dry weight, root dry weight, and moisture content. The results showed that slurry doses did not affect on the cocoa seedling growth.
\end{abstract}

Keywords: cocoa seedling, Theobroma cacao, slurry, Ultisols

DOI: http://dx.doi.org/10.25181/jaip.v7i2.1063

Diterima: 21 Maret 2019 / Disetujui: 7 September 2019 / Diterbitkan: 9 Oktober 2019

\section{PENDAHULUAN}

Kakao (Theobroma cacao L.) merupakan salah satu komoditas andalan nasional. Sejak awal tahun 1980-an, pertumbuhan dan perkembangan kakao semakin pesat di Indonesia. Tingkat Produksi bibit kakao sangat dipengaruhi oleh beberapa fakor antara lain bibit yang berkualitas, media tanam, dan proses budidaya. Tanaman kakao termasuk golongan tanaman tahunan yang tergolong dalam kelompok tanaman caulifloris, yaitu tanaman yang berbunga dan berbuah pada batang dan cabang. Tanaman ini pada garis besarnya dapat dibagi atas dua bagian, yaitu bagian vegetatif yang meliputi akar, batang serta daun dan bagian generatif yang meliputi bunga dan buah (Siregar \& Hartatik, 2010).

Tanaman kakao memerlukan penambahan unsur hara dengan cara pemupukan agar pertumbuhan dan produksi berlangsung optimal. Pemupukan adalah tindakan pemberian unsurunsur pada tanah yang dibutuhkan bibit kakao dengan menggunakan pupuk organik maupun pupuk 
anorganik. Penggunaan pupuk anorganik dalam waktu yang lama akan berdampak buruk terhadap mikroorganisme tanah dan menurunkan tingkat kesuburan tanah. Pupuk organik yang berbahan baku utama sisa makhluk hidup seperti kotoran, bulu, darah dan tulang yang mengalami proses pembusukan oleh mikroorganisme pengurai yang menghasilkan senyawa atau unsur-unsur yang dapat memperbaiki sifat fisik, kimia, dan biologi tanah serta dapat diserap oleh akar tanaman (Sajimin et al., 2005).

Bahan organik adalah kumpulan senyawa organik kompleks yang terdapat di dalam tanah termasuk seresah, mikroorganisme, dan humus (Stevenson, 1994 dalam Mohadi, 2008). Bahan organik dalam tanah dapat berfungsi dalam meningkatkan ketersediaan unsur hara dan aktivitas mikroorganisme (Winarso, 2005). Bahan organik juga terkandung dalam slurry yang merupakan limbah pembuangan digester biogas. Slurry dikelompokkan sebagai pupuk organik kerena seluruh bahan penyusunannya berasal dari bahan organik. Slurry berperan dalam memperbaiki struktur tanah, mengingkatkan kemampuan tanah dalam menyimpan air, meningkatkan aktivitas mikroorganisme tanah, dan sebagai sumber unsur hara bagi tanah (Suwarno \& Leiwakabessy, 2003). Oleh karena itu penambahan slurry dengan dosis yang terbaik perlu ditambahkan pada bibit kakao untuk meningkatkan pertumbuhan tanaman.

\section{METODE PENELITIAN}

Penelitian dilaksanakan di kebun percobaan, Laboratorium Analisis, dan Laboratorium Tanah Politeknik Negeri Lampung terhitung pada November 2017 sampai Maret 2018. Bahan yang digunakan dalam penelitian ini adalah benih kakao klon ICS 60, tanah top soil dari Ultisols Hajimena, pasir, air, polybag ukuran $20 \mathrm{~cm}$ x $25 \mathrm{~cm}$, slurry cair limbah kotoran sapi. Alat-alat yang digunakan dalam penelitian ini adalah cangkul, ember, gelas ukur, jangka sorong, penggaris, ayakan berlubang $2 \mathrm{~mm}$, pisau carter, oven, timbangan analitik, dan meteran. Penelitian ini menggunakan Rancangan Acak Kelompok (RAK) dengan 6 perlakuan dosis slurry, yaitu top soil (0 ml slurry), $80 \mathrm{ml}, 160 \mathrm{ml}, 240 \mathrm{ml}, 320 \mathrm{ml}$, dan $400 \mathrm{ml}$ yang diulang tiga kali, setiap ulangan terdiri atas 3 polybag.

Variabel pengamatan berupa pengamatan pendahuluan dan pengamanatan selama penelitian. Pengamatan pendahuluan berupa menganalisis kadar N, P, K. pH, dan C-Organik pada topsoil dan slurry. Pengamatan selama penelitian berupa tinggi tanaman, diameter batang, jumlah daun, bobot kering brangkasan, bobot kering akar, dan kadar air. Penelitian ini berlangsung pada 4 MST, 8 MST, 12 MST, 16 MST, dan 20 MST. Pengukuran kadar air tanah dilakukan dengan cara memanaskan sampel seberat $20 \mathrm{~g}$ kedalam oven dengan suhu $100^{\circ}-110^{\circ} \mathrm{C}$ selama $24 \mathrm{jam}$. Kemudian sampel tanah yang telah dikeluarkan dari oven ditimbang kembali Perhitungan kadar air tanah dapat dilakukan dengan rumus:

Kadar Air Tanah $=\frac{\text { Berat TanahBasah-Berat TanahKering }}{\text { Berat Tanah Kering }} X 100 \%$. 


\section{HASIL DAN PEMBAHASAN}

Berdasarkan analisis tanah dan slurry yang dilakukan pada awal penelitian, terdiri dari $\mathrm{N}$, $\mathrm{P}, \mathrm{K}, \mathrm{C}$-organik, dan $\mathrm{pH}$. Budidaya tanaman kakao dengan penggunaan bahan organik dapat meningkatkan kandungan unsur hara dalam tanah dan dapat menunjang pertumbuhan bibit kakao.

Tabel 1. Hasil analisis topsoil dan slurry

\begin{tabular}{lcc}
\hline Parameter & Topsoil & Slurry \\
\hline $\mathrm{N}(\%)$ & 0,47 (Sedang) & 0,60 (Tinggi) \\
$\mathrm{P}(\mathrm{ppm})$ & 12,50 (Rendah) & 9,20 (Sangat rendah) \\
$\mathrm{K}(\mathrm{me})$ & 0,80 (Tinggi) & 14,40 (Sangat tinggi) \\
$\mathrm{C}-$ organik $(\%)$ & 0,64 (Sangat rendah) & 2,74 (Sedang) \\
pH & 5,86 (Masam) & 6,76 (Netral) \\
$\mathrm{C} / \mathrm{N}$ Ration & & 4,56 \\
\hline
\end{tabular}

Sumber: Laboratorium Analisis Politeknik Negeri Lampung (2017); LPT (1984)

Berdasarkan hasil analisis pendahuluan, lapisan tanah top soil mengandung $0,47 \% \mathrm{~N}$ (sedang), 12,50 ppm P (rendah), dan 0,80 me K (tinggi). Hal ini menunjukkan bahwa tanah lapisan top soil jumlah rata-rata unsur $\mathrm{N}$, $\mathrm{P}$, dan $\mathrm{K}$ memliki kandungan yang cukup. Hal ini sesuai dengan pernyataan LPT, (1984). Hasil analisis pendahuluan slurry dari kotoran sapi mengandung unsur 0,60\% N (tinggi), 9,20 ppm P (sangat rendah), dan 14,40 me K (sangat tinggi). Berdasarkan hasil analisis slurry memiliki kandungan yang cukup, kecuali unsur hara P. Hal ini menunjukkan bahwa slurry masih dapat digunakan sebagai pupuk organik.

\section{Tinggi Tanaman}

Hasil analisis ragam menunjukkan bahwa pengaruh perlakuan yang tidak berbeda nyata. Penggunaan slurry sebagai bahan organik mampu mengikat air lebih baik dibandingkan dengan tanah tanpa bahan organik, sehingga dengan kandungan air yang cukup dan ketersedian unsur hara yang berasal dari slurry akan memacu pertumbuhan tanaman. Hasil penelitian Indriyani dan Umar (2011) menyatakan bahwa penggunaan bahan organik berpengaruh terhadap pertumbuhan vegetatif dan generatif tanaman. Pertumbuhan tinggi tanaman kakao disajikan pada Gambar 1. 


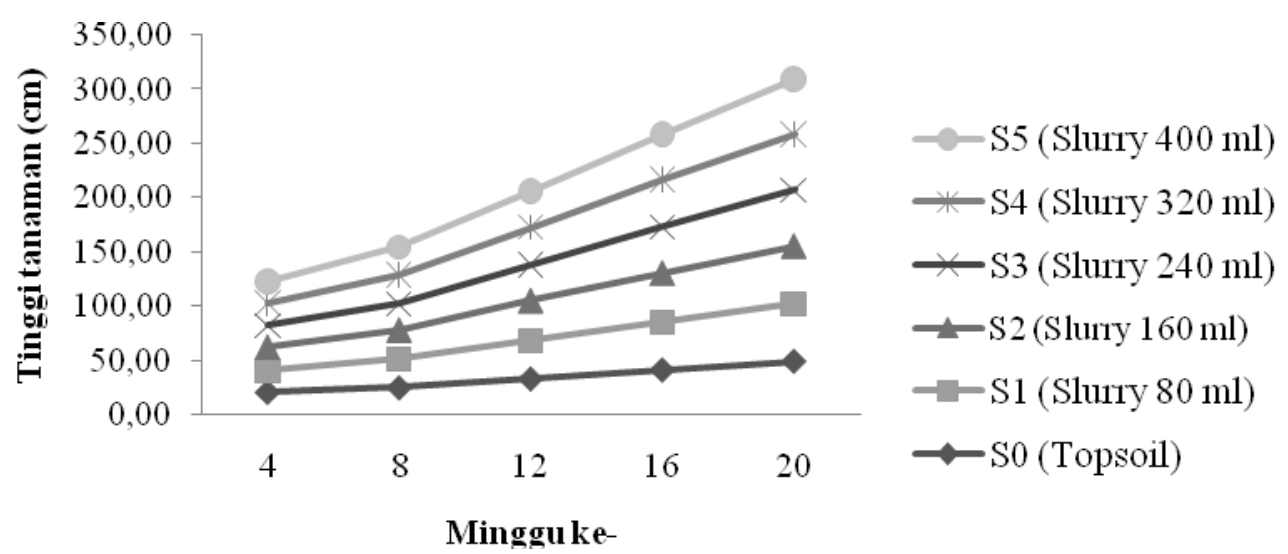

Gambar 1. Pertumbuhan tinggi tanaman kakao dengan perlakuan berbagai dosis slurry

\section{Jumlah Daun}

Berdasarkan analisis ragam, pengaruh perlakuan yang tidak berbeda nyata terhadap jumlah daun bibit kakao. Hal ini diduga karena ketersedian $\mathrm{N}$ dalam tanah sudah cukup untuk pertumbuhan tanaman kakao sehingga penambahan slurry tidak menunjukkan hasil nyata. Hal ini sejalan dengan pernyataan Wahyudi (2010) bahwa nitrogen berfungsi untuk meningkatkan pertumbuhan, sehingga daun tanaman menjadi lebar, berwarna lebih hijau, dan berkualitas.

Jika hasil dekomposisi bahan organik memiliki kandungan $\mathrm{N}$ total yang tinggi maka mikroorganisme yang terlibat dalam proses dekomposisi tidak akan kesulitan memperoleh nitrogen yang tersedia disekitarnya, sehingga tidak menyebabkan persaingan $\mathrm{N}$ bagi ketersediaan pada bibit kakao (Djurnani et al., 2006). Faktor lain yang menyebabkan jumlah daun tidak berbeda nyata diduga karena adanya sifat genetik. Sifat genetik merupakan sifat yang diturunkan dari tetua dan interval waktu munculnya daun yang tetap (Lakitan, 2011). Pertumbuhan jumlah daun kakao disajikan pada Gambar 2.

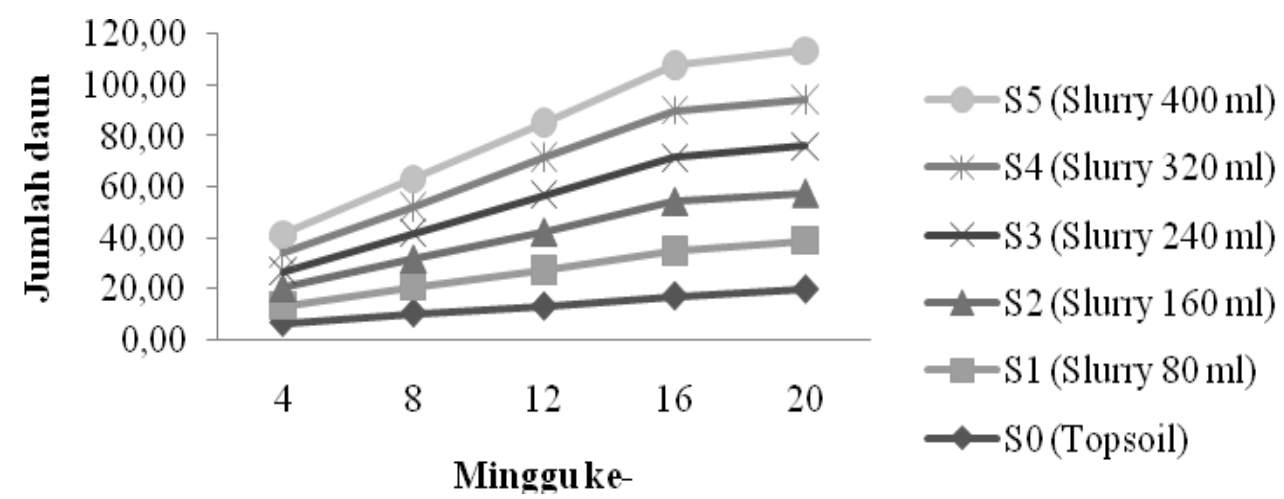

Gambar 2. Pertumbuhan jumlah daun kakao dengan berbagai perlakuan dosis slurry 


\section{Diameter Batang}

Hasil analisis dan sidik ragam menunjukkan pengaruh perlakuan yang tidak berbeda nyata. Hal ini diduga karena tanaman kakao memerlukan waktu yang relatif lama untuk meningkatkan diameter batang, sehingga umur yang singkat pada pengamatan tidak menunjukkan hasil yang berbeda nyata. Hal ini sejalan dengan pernyataan Uthbah et al. (2017) bahwa umur tanaman sangat mempengaruhi ukuran diameter batang, meningkatnya umur tanaman akan mempengaruhi ukuran diameter batang. Setyawan et al. (2004) menyatakan bahwa umur tanaman yang pendek akan menghasilkan diameter yang kecil dan sebaliknya pada umur tanaman yang panjang akan menghasilkan diameter yang besar. Pertumbuhan diameter batang kakao disajikan pada Gambar 3 .

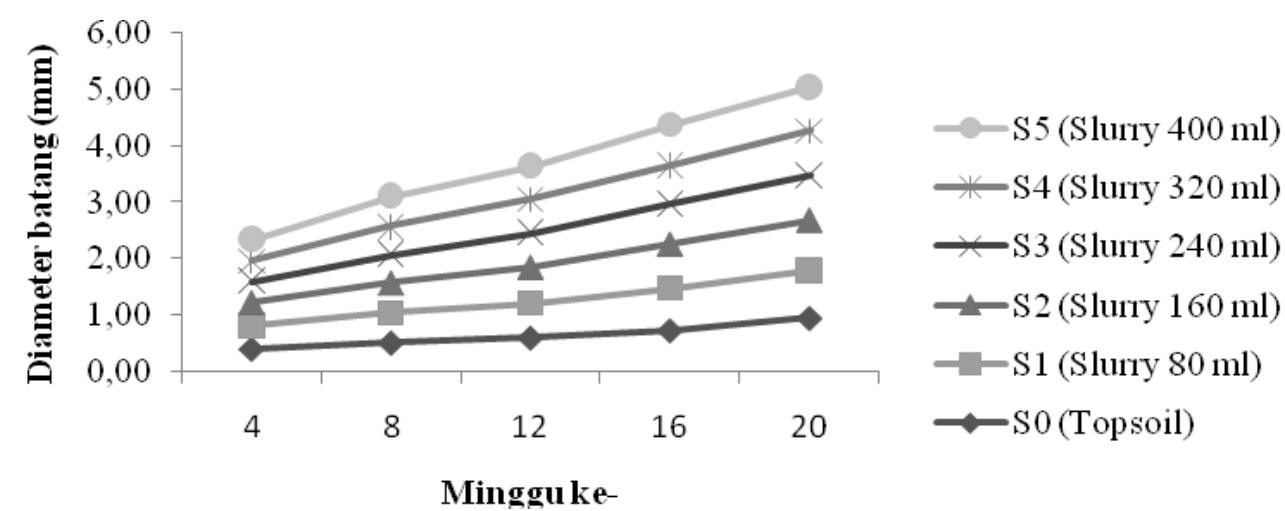

Gambar 3. Pertumbuhan diameter batang kakao dengan berbagai perlakuan dosis slurry

\section{Bobot Kering Brangkasan}

Hasil analisis sidik ragam menunjukkan bahwa perlakuan yang diberikan menunjukkan hasil yang tidak berbeda nyata. Hal ini diduga karena kandungan unsur hara terutama $\mathrm{P}$ yang seimbang pada tanah menghasilkan bobot kering berangkasan yang sama antar perlakuan yang diberikan. Hal ini sesuai dengan pendapat Nurahmi (2010) bahwa penambahan unsur hara sesuai dengan kebutuhan tanaman maka dapat meningkatkan produksi, apabila melebihi maka dapat menghambat pertumbuhan dan perkembangan tanaman. Rover (2009) juga menyatakan bahwa P berfungsi untuk pembentukan protein serta merangsang pembentukan akar sehingga menyebabkan pertumbuhan daun tanaman yang baik dan dapat meningkatkan bobot pada saat panen. Kandungan unsur hara terutama $\mathrm{P}$ yang seimbang menghasilkan bobot kering berangkasan yang sama antar perlakuan yang diberikan. Pengukuran bobot kering brangkasan disajikan pada Gambar 4. 


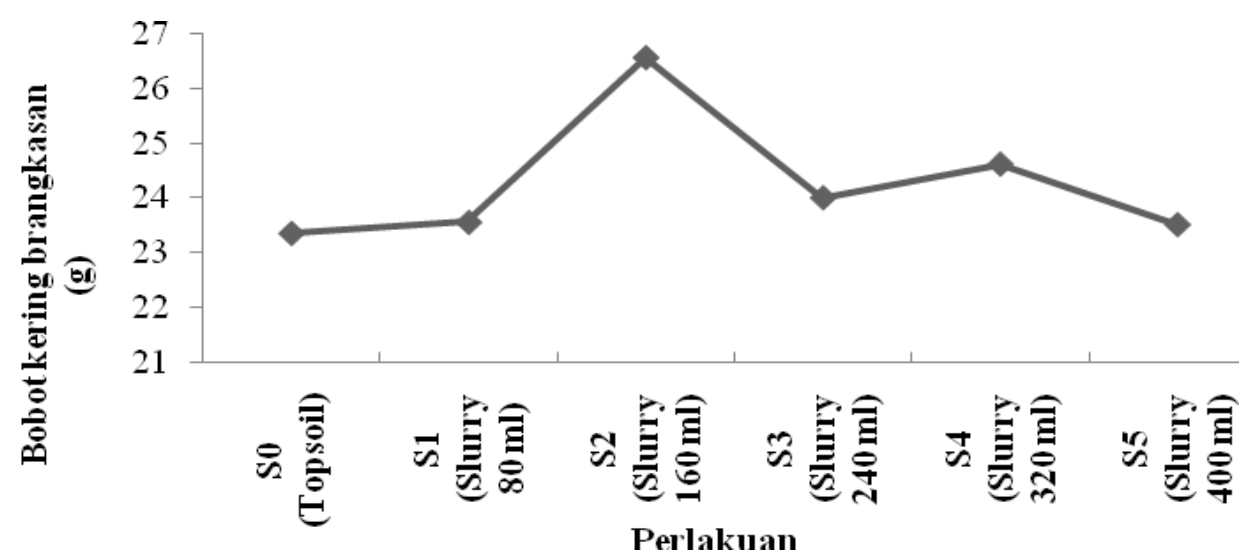

Gambar 4. Pengamatan bobot kering brangkasan tanaman kakao pada 20 MST dengan berbagai perlakuam dosis slurry

\section{Bobot Kering Akar}

Hasil analisis sidik ragam menunjukkan bahwa pengaruh perlakuan yang tidak berbeda nyata. Hal ini diduga karena slurry sebagai bahan organik dapat meningkatkan unsur hara pada tanah sehingga menyebabkan pertumbuhan akar yang seragam. Marschener (1999) dalam Kanatakan (2017) menyatakan bahwa proses fotosintesis terjadi di daun dan perpindahan energi akan di akumulasikan pada bagian tanaman seperti batang dan akar. Khamis (1999) dalam Kanatakan (2017) menambahan bahwa peningkatan karbohidrat yang ditandai penimbunan sukrosa di akar dapat menurunkan rasio berat kering akar. Pengukuran bobot kering akar disajikan pada Gambar 5 .

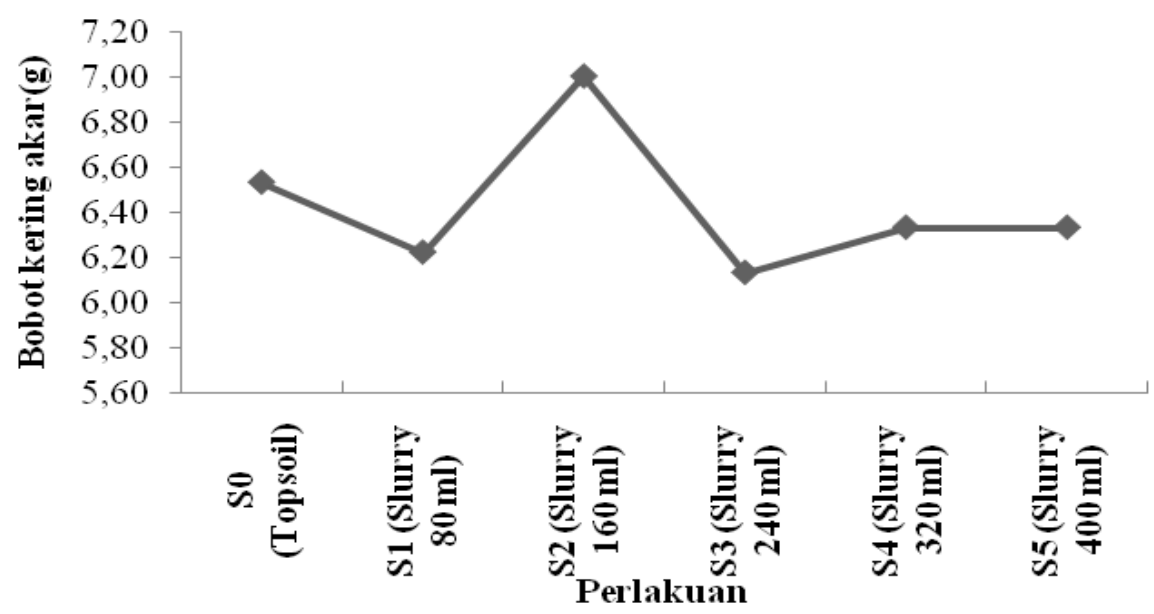

Gambar 5. Pengamatan bobot kering akar tanaman kakao pada 20 MST dengan berbagai perlakuam dosis slurry

\section{Kadar Air}

Hasil analisis ragam menunjukkan bahwa pengaruh perlakuan tidak berbeda nyata. Hal ini diduga rendahnya bahan organik yang terkandung dalam slurry. Hanafiah (2007) mengatakan bahwa kadar air tanah dipengaruhi oleh kadar bahan organik tanah, makin tinggi bahan organik Jurnal AIP Volume 7 No. 2 | Oktober 2019: 69-76 
tanah akan mempengaruhi tinggi kadar air. Slurry memiliki beberapa manfaat menyuburkan tanah pertanian dengan kemampuannya menetralkan tanah yang masam dengan baik, menambah kadar humus untuk kesuburan tanah sehingga lebih bernutrisi dan mampu menyimpan air (Tim Biogas Rumah, 2013). Pengukuran kadar air disajikan pada Gambar 6.

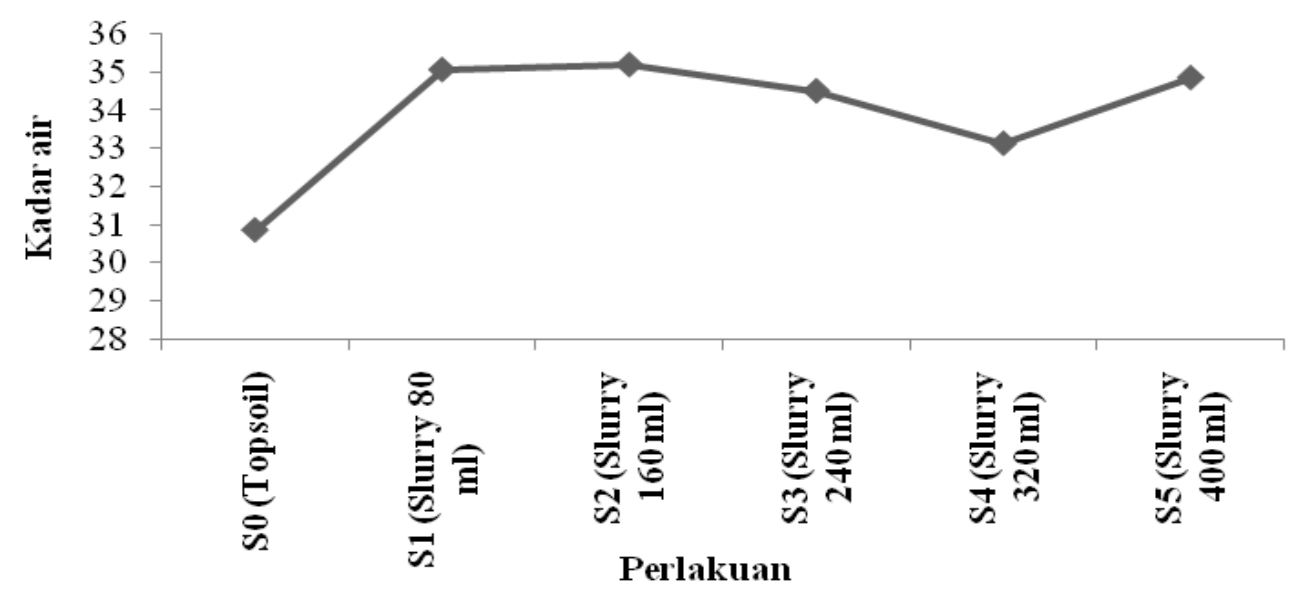

Gambar 6. Pengamatan kadar air pada 20 MST dengan beragai perlakuan dosis slurry

\section{KESIMPULAN DAN SARAN}

\section{Kesimpulan}

Hasil penelitian ini bahwa pemberian berbagai dosis slurry $(0 \mathrm{ml}, 80 \mathrm{ml}, 160 \mathrm{ml}, 240 \mathrm{ml}$, $320 \mathrm{ml}$, dan $400 \mathrm{ml}$ ) tidak menunjukkan pengaruh terhadap pertumbuhan bibit kakao sampai dengan umur 20 minggu setelah tanam.

\section{Saran}

Media pembibitan top soil yang umumnya sudah subur tidak perlu diberi slurry. Perlu dilakukan peneliitian lanjutan dengan menggunakan media tanah sub soil.

\section{DAFTAR PUSTAKA}

Djunanri, N., Kristina, B. S, \& Setiawan. (2006). Cara-cara Cepat Membuat Kompos. Jakarta: Penerbit Bhatara Karya Astra Aksara.

Hanafiah, K. A. (2007). Dasar-dasar Ilmu Tanah. Jakarta: PT. Raja Grafindo.

Indriyani, L. \& Umar, S. (2011). Pengaruh pemupukan N, P, K dan bahan organik terhadap pertumbuhan dan hasil kedelai di lahan sulfat masam bergambut. Jurnal Agrista, 15(3), 47-52.

Kanatakan, A. (2017). Pengaruh Pemberian Nitrogen dan Fosfor terhadap Pertumbuhan Legum (Colopogonium mucunoides, Cetrosema pubescens \& Arachis pintoi). Unpublished undergraduate thesis. Universitas Jambi. Jambi. 
Karmawati, E., Zainal, M., Joni, M., Ketut, A., \& Rubiyo. (2010). Budidaya dan Pasca Panen Kakao. Bogor: Pusat Penelitian dan Pengembangan Perkebunan.

Lakitan, B. (2011). Dasar-dasar Fisiologi Pertumbuhan. Jakarta: PT Raja Grafindo Persada.

LPT (Lembaga Penelitian Tanah). (1984). Penuntun Analisa Fisika Tanah. Jakarta: Badan Penelitian dan Pengembangan Pertanian.

Mohadi, R., Hidayati, N., Santosa, \& Narsito. (2008). Karakteristik Asam Humat dari Gambut Indralaya Ogan Ilir Sumsel. Unpublished undergraduate thesis. Universitas Sriwijaya, Palembang.

Nurahmi, E. (2010). Kandungan Unsur hara tanah dan tanaman selada pada tanah bekas tsunami akibat pemberian pupuk organik. Jurnal Floratek, 5(1),74-85.

Rover. (2009). Pemberian Campuran Pupuk Anaorganik dan Pupuk Organik pada Tanah Ultisols Untuk Tanaman Padi Gogo (Oryza sativa. L). Unpublished graduate thesis. Universitas Islam Riau. Pekanbaru.

Setyawan, D., Ina,W., \& Sumadiwangsa, E. S. (2004). Pengaruh tumbuh, jenis dan diameter batang terhadap produktivitas pohon penghasil biji tengkawang. Jurnal Penelitian Penghasil Hutan, 22(1), 23-33.

Siregar, A. \& Hartatik, W. (2010). Aplikasi Pupuk Organik dalam Meningkatkan Efisiensi Pupuk Anorganik pada Lahan Sawah. Bogor: Balai Penelitian Tanah.

Suwarno, W. U., \& Leiwakabessy, F. M. (2003). Kesuburan Tanah. Bogor: Departemen Tanah, Fakultas Pertanian, Institut Petanian Bogor.

Tim Biogas Rumah (2013). Pedoman penggunaan dan pengawas pengelolaan dan pemanfaatan bioslurry. Pedoman pengguna dan pengawas pengelolaan dan pemanfaatan bio-slurry. http://sfiles.biru.or.id/uploads/files/ 1383206022. pedoman\%20pengawas.pdf. Diakses 20 Oktober 2018.

Uthbah, Z., Eming, S., \& Edy, Y. (2017). Analisis biomassa dan cadangan karbon pada berbagai umur tegakan tamar (Agathis dammara (Lamb.) Rich) KPH Banyumas Timur. Jurnal Sucipta Biologi, 4(2), 119-124.

Wahyudi. (2010). Petunjuk Praktis Bertanam Sayuran. Jakarta: Agromedia Pustaka.

Winarso, S. (2005). Kesuburan Tanah Dasar Kesehatan dan Kualitas tanah. Yogyakarta: Gava Media. 